\title{
Intim részletek. A magyar szociológia történetének hangoskönyve
}

\author{
Eróss Gábor \\ https://doi.org/10.51624/SzocSzemle.2018.1.8
}

\section{Bevezetés. Kettős feltárulkozás}

A konferenciát ${ }^{1}$ Kovács Éva nyitotta meg, aki a KDK-t (az MTA Társadalomtudományi Kutatóközpontjában múködő Kutatási Dokumentációs Központot)² és az attól elválaszthatatlan 20. Század Hangja Archívum és Kutatómühelyt, az egész - most születésnapját ünneplő - projektet „megálmodta” és vezeti. Szemléletes képpel írta le, milyen is a társadalomkutató számára, ha a régi interjúkazettáit, kérdőíveit, jegyzetlapjait oda kell adnia az Archívum számára: „Egy interjút nyersen odaadni kicsit olyan, mintha a fehérnemüjét adná oda az ember”. És tényleg: az Archívum funkciója kettős: feltárul, illetve feltárhatóvá válik a magyar szociológia múltja és kitárulkoznak maguk a szociológusok: ez vagyok én, ezek vagyunk mi. A konferenciának is azok voltak a nagy pillanatai, amikor ezekre az „intim részletekre” fény derült, amikor Csanádi Gábor mesélt élőben a közel 40 évvel ezelőtti iskolaiszegregáció-kutatásról (Ladányi-Csanádi 1983), vagy a közönség sorai közt „rejtőző” Kovács Katalin demográfus állt fel és mesélt a Dialógus békemozgalomról, melynek maga is részese volt.

\section{Aranykor, civil kurázsi}

A magyar szociológia aranykorát a 70-es, 80-as évek jelentik, ez az időszak adja a gyüjtemény gerincét. A főbb témák, mint azt Kovács Éva kiemelte: életmód, cigányság, fogyasztás.

Volt ezekben a kutatásokban, ahogy a bevezetőben is írja Kovács Éva, egy eredendő spontaneitás, amit ma grounded theory-nak nevezünk. És volt sok-sok beszélgetés a kutatók közt, az autóban, a Volán-buszon, melyek elillantak (verba volant...), s melyeket legfeljebb csak az életútinterjúk alapján rekonstruálhatunk, ha mozaikosan és részlegesen, az emlékezés sűrű szövetû szűrőjén átszűrve is. Ültek a kutatók együtt és hosszan-hosszan beszélgettek - de sajnos ezt nem dokumentálták. Ami jellemezte őket - a csodálkozás, a kíváncsiság, a termékeny bizonytalanság -, az szemben áll a

1 VOICES10 Konferencia a 20. Század Hangja Archívum és Kutatómúhely 10. születésnapján. MTA TK Szociológiai Intézet, Humán Tudományok Kutatóháza, 2017. november 23-24. http://20szazadhangja.tk.mta.hu/uploads/files/voices10_poster_a3.pdf.

2 Az MTA TK KDK-ban tájékozódhat a Kutatóközpont kutatói által végzett kutatásokról, kutatási gyưjteményekbe tekinthet be, teljes kutatási dokumentációkat és nyersanyagokat tölthet le (http://kdk.tk.mta.hu/). 
szociológia bevett, rendszerváltás utáni sablonjaival és általában is a mainstream szociológia kánonjának szúk hangtartományával. A 20. Század Hangja több oktávot fog át, és így hoz, illetve hozott létre tudományosan is érvényes tudást.

Amit viszont biztosan tudunk és Kovács Éva is emlékeztetett rá, az az, hogy a tudományos megismeréshez szükséges volt a civil kurázsi, akár Kemény Istvánra, akár Ambrus Péterre, akár Csalog Zsoltra, akár Mátyus Alizra gondolunk - és a sor ennél jóval hosszabb. A tudomány és a rendszerkritika egybeforr. A szociológia aktorai között ott vannak a demokratikus ellenzék tagjai, így az aktivista tudást hozzák be például a SZETA-n keresztül; nem kérdés, elkötelezett-e a kutató. Ugyanakkor voltak, akik nem tudtak alámerülni és nem tudták kibekkelni: Szelényi Ivánnak például el kellett hagynia a hazáját. A kurázsi - courage - egyébként egy másik, Kovács Éva vezette kapcsolódó projekt nevére is utal, amely a szocialista korszakbeli kulturális ellenállás kelet-európai alakzatait és ezek gyűjteményeit kutatja (lásd pl.: Szőts 2016).

\section{Szerzetesrendek}

Bögre Zsuzsanna előadása a „Földalatti szerzetesrendek 1950-1989 között” címet viselte. Bögre vallásszociológusként asszonysorsokon, apácasorsokon keresztül tárja fel a múltat, kutatása levéltári munkán és idős apácákkal készített interjúkon alapul. Amikor - a 40-es évek végére, az 50-es évek elejére - a korábban létezett több tucat szerzetesrend közül csak négy férfi rend maradhatott meg, a szerzetesek, apácák előtt több út állt (emlékezzünk Sartre szabadság-paradoxonára: „sohasem voltunk olyan szabadok, mint a náci megszállás alatt”). Ugyanakkor, mint Bögre Zsuzsanna megjegyezte, még az aszkéták (a kismarosi monasztikus rendiek) sem tudtak teljesen kivonulni.

Bögre Zsuzsanna szerint azt valójában nem tudhatjuk, ténylegesen hányan éltek illegalitásban, mert mára már presztízst (szimbolikus tőkét) növelő tényező, ha valaki ezzel büszkélkedhet. Voltak tehát, akik maradhattak a rendszer szabta szúk keretek között, mások a „földalatti” ellenállást választották, megint mások a „szétszóratás” (a belső vagy külső száműzetés) stratégiáját. Legtöbbjük számára az alábbi négy lehetőség maradt: vállalni a nehéziparban a legnehezebb fizikai munkát, háztartási alkalmazotti státuszhoz jutni idegen családoknál, kisegítő munkát találni plébániákon, illetve visszatérhettek a családjukba (részletesen lásd: Bögre 2017).

\section{Megelevenedő történelem}

Tóth Eszter Zsófia, a Veritas Történetkutató Intézet kutatója a Dialógus békemozgalommal és a Mozgó Világ védelmében létrejött mozgalommal foglalkozott, foglalkozik. A Dialógust a rendszer 83-ra szétverte, holott célkitűzései elvileg egyeztek a rezsim céljaival. Tóth Eszter Zsófia az ő rendszerbomlasztó hétköznapjaikba engedett bepillantást: a „veszélyes fiatalok” hol Keszthelyen csavarognak, hol békejelvény tǔznek ki, hol az atomfegyvermentes Európáért emelnek szót. De bármit tesznek is, ellenőrzés 
nélkül nem tehetik. „Természetesen” volt köztük, aki jelentett, akit, ahogy a többi beépített ügynököt is, úgy szerveztek be, hogy a szüleikkel zsarolták, vagy az iskolával: hogy nem végezhetik el. A mozgalmat végül úgy verték szét, hogy a budapesti mozgalomba beépítettek két embert - hogy ne születhessen érdemi döntés; vagy például, amikor angol fiatalokat vártak látogatóba, „lekapcsolták” őket a Keletiben.

Körülbelül ezen a ponton megelevenedett a történelem: egyszer csak megjelent a mozgalom egyik tagja, Tajta Gábor, és elkezdett mesélni. Azután Kovács Katalin is. Tajta azóta is nehéz sorsú fiatalokat segít, a Belvárosi Tanodát vezeti. Kovács Katalin demográfus a KSH-ban. A többiek sem szakadtak el egészen a „békemozgalmi” gyökerektől, a kulturális ellenállástól - vagy legalábbis a kultúrától: van köztük, aki jelenleg az A38-as programszervezője, megint más olvasott utazási blogger.

\section{Szabadság és egyenlőség az iskolában}

Lődi Virág és K. Horváth Zsolt „Kritikai és vizuális pedagógiai kísérletek budapesti iskolákban 1978-1985 között” címmel adtak elő. K. Horváth Zsolt az eszmetörténeti, hatástörténeti alapokat rakta le. Rámutatott, hogy Mannheim Károly közvetett hatása is kimutatható a köznevelési reformra. Mannheim gondolata - a „tervezés a szabadságért" - Bibó István ismertetésén keresztül hatott Mérei Ferencre és Kiss Árpádra, Faragó László pedig tudatosan alkalmazta Mannheimnek a tudásszociológiát a neveléstudománnyal ötvöző gondolatait. Mannheim „javaslata az, hogy el kell szakadni a laissez-faire liberalizmus megmerevedett, a valóságtól elszakadt ideológiájától, és az egyenlőtlenségek kezelése végett az államnak be kell avatkoznia. Ennek az intervenciónak válik kulcsszavává az - azóta sokszor félreértett - tervezés fogalma" (K. Horváth 2018).

$\mathrm{Az}$ államszocializmus idején is, eleinte - francia és brit mintára - a közoktatás demokratizálását vették tervbe. Az 1945-ös köznevelési reformra, melynek Mérei mellett Kiss Árpád és - a Mannheim nézeteit tudatosan adaptáló - Faragó László volt a motorja, elsősorban „az 1944-es brit Education Act és a francia LangevinWallon-terv irányelvei voltak mértékadóak, neveléselméleti értelemben pedig Dewey, Claparède, Piaget, Wallon, Lewin, Montessori, Lighthart jelentették az alapot" (K. Horváth 2018).

Eszerint a társadalmi egyenlőtlenségek csökkentése és a demokrácia meggyökereztetése kéz a kézben járnak. Az emancipatorikus közneveléssel és közművelődéssel kapcsolatban Mérei Ferenc a „szocialista felvilágosodás” programját hirdette meg. Trencsényi László hozzászólásában Karácsony Sándor, Vitányi Iván, Lévai „Süsü” Sándor és Winkler Márta nevét említette, mint olyan, a közoktatás és a közmúvelődés területén dolgozó személyekét, akik hasonló elvek szerint végezték munkájukat. A Nékosz idején, 1945 és 1948 között rövid ideig úgy tűnt, a rendszer központi eleme, küldetése lesz az oktatási rendszer demokratizálása és a társadalom mobilitási csatornáinak egyidejű megnyitása. Ennek az „utópiának” a megálmodói később az 
iskola világának legkülönbözőbb szögleteiben jelentek meg, illetve egyre tágították ezt a világot: ebben a kontextusban értelmezhető a táncházak, a drámapedagógia, az olvasótábori mozgalom (Kamarás István) - vagy éppen a vizuális pedagógia kibontakozása is (amiről az alábbiakban írok). Az iskola észrevétlenül megújult, ha egyenlővé és szabaddá nem is vált.

\section{Rom Som és „Tettek ideje...”}

György Eszter előadásában a rákospalotai Rom Som történetét dolgozta fel, ahová olyan meghatározó cigány értelmiségiek jártak, mint Péli Tamás, Choli Daróczi, vagy éppen Daróczi Ágnes. Valamelyikük így emlékszik vissza: „azt hitték, nagy tömeg ( $a$ cigány értelmiség) van mögöttünk, pedig csak öten voltunk”. Egy idő után betiltották a Rom Som újságot, de a klub múködhetett tovább. Az önszerveződés elbukott, azonban, György Eszter szerint, az önszerveződők máig is aktívak, kifejtik hatásukat. Daróczi Ágnes - civilben költő - például ma is az egyik legaktívabb és legnagyobb hatású roma közéleti aktivista.

És nem csak az aktivizmus maradt meg, hanem a cigányság ügye iránt elkötelezett társadalomkutatói közeg is. Az a kutatási hagyomány, amely ekkortájt - a Rom Somtól csak látszólag függetlenül ${ }^{3}$ - kialakult, s amelyre Kovács Éva is utalt a konferencia bevezetőjében, s amely azóta is az egyik legerősebb vonulata a magyar szociológiának (pl. Szalai-Schiff 2014), de a kulturális antropológiának is (Erőss 2012).

Csengei Andrea előadásnak már a címében is teremtő feszültség érződik: „Tettek ideje: egy kiállításról”. Hogy a tettek és egy kiállítás hogyan kapcsolódik egymáshoz? Úgy, hogy egy részvételi akciókutatásról van szó, melynek produktuma egy rendhagyó kiállítás volt. A Közélet iskolájának égisze alatt lezajlott kutatás célja a lakhatási mozgalmak történetének feltárása: a barlanglakásokban élők élete, a félkész házgyári lakások elfoglalása, az 56-os lakásfoglalások (a lakásfoglalók büntetést fizettek, s ezzel hivatalossá vált a státuszuk), a 89-es spontán fekvősztrájk a Blaha Lujza téren, a Déliben, a Keletiben. Ez utóbbi akkor robbant ki, amikor a pályaudvarokról kizárták a hajléktalanokat. Amikor azok a Keletiben elfoglalták a várót, a MÁV-dolgozók sztrájkkal feleltek; azután a MÁV felajánlott egy épületet, ami azóta is hajléktalanszállóként múködik. Az akciókutatásból - melyben hajléktalan emberek is részt vettek - kiállítás lett a Kassák Múzeumban, amely elnyerte a Sozial-Marie-díjat.

\section{A köpeny alatt. Élménypedagógia}

Ezután kerekasztal-beszélgetés következett „Párhuzamos vizuális kísérletek 1990 előtt” címmel, melynek teljes rekonstrukciójára nem teszek kísérletet, néhány mozza-

3 A Daróczi Ágnes által a 70-es évek végén a Népművelési Intézetben szervezett, romákkal foglalkozó továbbképzések rendszeres vendége volt például Havas Gábor szociológus (Láng: é. n.). 
natot azonban kiemelek - amelyek a legpregnánsabban jelzik és jellemzik a rendszerváltás előtti magyar társadalomkutatás karakterét.

A Szociológiai Intézet nemrég hátrahagyott várbeli főhadiszállásán egyszer gyerekrajzok estek ki a szekrényből; H. Sas Judit kutatási anyaga volt, amelyet nem dolgoztak fel. Épp az ilyen és ehhez hasonló leletek felfedezése, rendszerezése és archiválása a Kovács Éva vezette KDK célja.

Csanádi Gábor mesél. Az „állami telepen” (a mai Havannán) iskolai szegregációt kutattak. A rajzok, az iskolai naplók és interjúk alapján kibontakozó valóság más, mint amit a rendszer állított magáról: nagyok a különbségek az iskolák között. Ha heterogén beiskolázási körzet van, akkor a párhuzamos osztályok között szelektálnak.

A gyerekek zoknija, cipője, haja más és más - attól függően, melyik osztályba járnak. Pedig kötelező az iskolaköpeny. A tanárokat is szelektálják. De persze a szegregáció legkeményebb eszköze a kisegítő iskola. Az áttelepítési eljárás során a pszichológus, aki dokumentumok alapján dönt, gyerekrajzokat is csináltatott. A gyerekek 2/3-a valójában nem volt értelmi fogyatékos. Csanádiék azokat a kérdéseket fogalmazták meg akkor, amiket az oktatásszociológia azóta is, újra meg újra: hogyan teszi elfogadottá „a rendszer” a szelekciót, az egyenlőtlenségeket, a kirekesztést, a haszonélvezőkkel pedig miképpen hiteti el, hogy a kiváltságaik érdemeik szerint járnak? (Lásd: Berényi-Berkovits-Erőss 2008). A kutatók beültek a felvételikre is; volt, akinek a szüleit a tanító néni már ismerte, vagy aki a „megbízható” x utcai óvodából jött; ha a roma gyerekek mégis bekerültek, előbb-utóbb kihullottak. A társadalmi egyenlőtlenségek jól ismert mechanizmusai múködtek akkor, s müködnek azóta is.

A 70-es évek végén, 80-as évek elején Rév István tartott rajzszakkört a légópincében - azt tanította a gyerekeknek, amit az egyetemen. Az élménypedagógiát a végsőkig feszítette: az volt a téma, hogyan kell megtervezni a város szegénynegyedének a felgyújtását, és tűz is lett az alagsorban. Keresztes háborút is szervezett. Meg akarta gyülöltetni a gyerekekkel a tekintélyeket. Ezekkel a gyerekekkel később is sok baj volt, sztrájkba léptek, barikádokat építettek. Lehet-e kifejezőbb metaforával leírni a kulturális ellenállást?

S lehet-e fontosabb a szociológia számára, mint megismerni saját múltját - beleértve a légópincében, iskolában is alkalmazott társadalomtudományt?! A konferencia első napja is egy olyan dokumentumfilm vetítésével zárult, amely épp az - egyenlősítő célzatú - iskolai vizuális pedagógiai kísérletek egyikét mutatta be, amelyet egy budapesti, panelrengetegövezte általános iskolában folytattak; a múlt itt is megelevenedett: a „Tárgyilagos kép” vetítésére és az azt követő beszélgetésre a rendező, Péterffy András is eljött. S ez a „kettős feltárulkozás” folytatódott a konferencia második napján is.

\section{Irodalom}

Berényi E. - Berkovits B. - Erőss G. (2008): Iskolarend. Kiváltság és különbségtétel a közoktatásban. Budapest: Gondolat. 
Bögre Zs. (2017): Hűségesnek maradni. Apácasorsok a kommunizmusban. 2017. március 23. https://ppke.hu/aktualis/husegesnek-maradni.

Erőss, G. (2012): Central Europe: Bulgaria, the Czech Republic, Hungary, Poland, Romania, Slovakia. In: K. M. Anderson-Levitt (ed.). Anthropologies of Education: A Global Guide to Ethnographic Studies of Learning and Schooling. New York; Oxford: Berghahn Books, 167-192.

K. Horváth Zs. (2018): Köznevelés és demokratikus értékpolitika. Új Egyenlöség, 2018. február 6. http://ujegyenloseg.hu/kozneveles-es-demokratikus-ertekpolitika/.

Ladányi J. - Csanádi G. (1983): Szelekció az általános iskolában. Budapest: Magvető.

Láng J. (é. n.): Roma florklór-mozgalom A művészet erejével megmutatni magunkat (interjú Daróczi Ágnessel és Bársony Jánossal). http://www.demokrata.info/ component/tags/tag/85-roma-florklor-mozgalom.

Szalai, J. - Schiff, C. (eds.) (2014): Migrant, Roma and Post-Colonial Youth in Education across Europe. Being 'Visibly different'. Basingstoke: Palgrave.

Szőts Z. O. (2016): Párhuzamos ellenállások. Az ellenzékiség kultúrája a szocializmus idején. http://ujkor.hu/content/parhuzamos-ellenallasok-az-ellenzekisegkulturaja-a-szocializmus-idejen. 